\title{
Effects of Chronic Buspirone Treatment on Cocaine Self-Administration
}

\author{
Nancy K Mello*,', Peter A Fivel', Stephen J Kohut' and Jack Bergman' \\ 'Alcohol and Drug Abuse Research Center, Harvard Medical School-McLean Hospital, Belmont, MA, USA
}

\begin{abstract}
Cocaine abuse and dependence is a major public health problem that continues to challenge medication-based treatment. Buspirone (Buspar) is a clinically available, non-benzodiazepine anxiolytic medication that acts on both serotonin and dopamine systems. In recent preclinical studies, acute buspirone treatment reduced cocaine self-administration at doses that did not also decrease food-reinforced behavior in rhesus monkeys (Bergman et al, 20 I2). The present study evaluated the effectiveness of chronic buspirone treatment on selfadministration of cocaine and food. Five adult rhesus monkeys (Macaca mulatta) were trained to self-administer cocaine and food during four I-h daily sessions under a second-order schedule of reinforcement (FR2 [VR I6:S]). Buspirone (0.32 and 0.56 mg/kg/h) was administered intravenously through one lumen of a double-lumen catheter every $20 \mathrm{~min}$ for $23 \mathrm{~h}$ each day for 7-10 consecutive days. Each buspirone treatment period was followed by saline control treatment until drug- and food-maintained responding returned to baseline levels. Buspirone significantly reduced responding maintained by cocaine, and shifted the dose-effect curve downwards. Buspirone had minimal effects on food-maintained responding. In cocaine discrimination studies, buspirone $(0.1-0.32 \mathrm{mg} / \mathrm{kg}$, IM) did not antagonize the discriminative stimulus and rate-altering effects of cocaine in four of six monkeys. These findings indicate that buspirone selectively attenuates the reinforcing effects of cocaine in a nonhuman primate model of cocaine self-administration, and has variable effects on cocaine discrimination.

Neuropsychopharmacology (2013) 38, 455-467; doi: I0.1 038/npp.2012.202; published online 17 October 2012
\end{abstract}

Keywords: buspirone; cocaine; drug self-administration; dopamine $\mathrm{D}_{3}$ receptor; dopamine $\mathrm{D}_{4}$ receptor; 5-HTIA

\section{INTRODUCTION}

Buspirone (Buspar) is a non-benzodiazepine anxiolytic approved by the FDA for the treatment of anxiety. Buspirone has a complex pharmacology and its mechanisms of anxiolytic action are poorly understood. Both dopamine and serotonin receptors appear to contribute to buspirone's behavioral effects. Buspirone acts as a $5-\mathrm{HT}_{1 \mathrm{~A}}$ partial agonist (Newman-Tancredi et al, 1998; Wong et al, 2007), and also binds to dopamine $\mathrm{D}_{2}, \mathrm{D}_{3}$, and $\mathrm{D}_{4}$ receptors (Bergman et al, 2012; Kula et al, 1994; Tallman et al, 1997). In addition to amelioration of anxiety, buspirone has also been used to reduce cigarette smoking (Cinciripini et al, 1995; Henningfield et al, 2005; Hilleman et al, 1992; West et al, 1991) and is being considered for treatment of marijuana dependence and withdrawal (Elkashef et al, 2008; McRae-Clark et al, 2009; Weinstein and Gorelick, 2011). Buspirone has been well tolerated in clinical studies, and there is little evidence of abuse liability in humans (Griffith

*Correspondence: Dr NK Mello, Alcohol and Drug Abuse Research Center, Harvard Medical School-McLean Hospital, I I5 Mill Street, Belmont, MA 02478, USA, Tel: +I 617855 2746, Fax: + 617855 2519, E-mail: nmello@mclean.harvard.edu

Preliminary data were reported at the 2011 meeting of the American College of Neuropsychopharmacology.

Received 20 June 2012; revised 28 August 2012; accepted 29 August 2012 et al, 1986). Recent interest in buspirone for the treatment of cocaine abuse and dependence is based in part on evidence that buspirone has dopamine $\mathrm{D}_{3}$ and $\mathrm{D}_{4}$ selective actions, which may mediate its ability to decrease cocaine self-administration (Bergman et al, 2012).

Many preclinical studies have evaluated the effects of buspirone on the abuse-related characteristics of cocaine, and most have concluded that buspirone's interactions with cocaine reflect its dopamine $\mathrm{D}_{2}$ antagonist properties. Neuropharmacological studies have demonstrated that buspirone selectively blocks the $\mathrm{D}_{3}$ and $\mathrm{D}_{4}$ subtypes of the $\mathrm{D}_{2}$ receptor and that this selectivity extends to its dopamine antagonist effects in the functional $\beta$-arrestin assay (Bergman et al, 2012; Kula et al, 1994). This is of interest because of the suggested importance of dopamine $\mathrm{D}_{3}$ and $\mathrm{D}_{4}$ receptors in the abuse-related effects of cocaine, and therefore, in the design of candidate treatment medications. The potential role of dopamine $\mathrm{D}_{3}$ and $\mathrm{D}_{4}$ receptor antagonists and partial agonists in drug abuse treatment medications has stimulated considerable research (see for review Heidbreder et al, 2005; Heidbreder and Newman, 2010; Le Foll et al, 2005; Le Foll et al, 2000; Newman et al, 2005; Newman et al, 2012). The recent discovery of buspirone's dopamine $\mathrm{D}_{3}$ and $\mathrm{D}_{4}$ antagonist activity, combined with our observation that an acute dose of buspirone reduced cocaine self-administration by rhesus monkeys (Bergman et al, 2012), led us to examine the effects 
of chronic treatment with buspirone on cocaine selfadministration, as well as the effects of buspirone pretreatment on cocaine discrimination.

The effects of buspirone on the abuse-related effects of cocaine have been inconsistent across species and test procedures. In nonhuman primates, buspirone did not share discriminative stimulus properties with cocaine (Koetzner, 1996) and did not maintain self-administration (Balster, 1990; Balster and Woolverton, 1982; Griffiths et al, 1991), suggesting that buspirone may have relatively low abuse potential. In drug discrimination studies in rodents, buspirone also did not substitute for cocaine, but either dose-dependently reduced cocaine-appropriate responding and shifted the cocaine dose-effect function to the right (Callahan and Cunningham, 1997), or had no effect (Rapoza, 1993). The effects of buspirone on the reinforcing effects of cocaine in nonhuman primates have not been widely studied. Early studies in rhesus monkeys showed that acute treatment with buspirone $(0.1-0.56 \mathrm{mg} / \mathrm{kg})$ significantly increased cocaine self-administration, whereas a high dose, $1.0 \mathrm{mg} / \mathrm{kg}$, significantly decreased rates of cocaine self-administration under a fixed ratio (FR) 10 schedule of reinforcement (Gold and Balster, 1992). Rateincreasing effects of buspirone also were observed under a second-order schedule of IV cocaine self-administration in squirrel monkeys (Nader and Barrett, 1990). The effects of chronic buspirone treatment on cocaine self-administration also have not been widely studied. In contrast to buspirone's acute effects, daily treatment with the relatively low single doses $(0.1$ and $0.3 \mathrm{mg} / \mathrm{kg}$, IV) had little effect on cocaine self-administration over a 10-day period (Gold and Balster, 1992). It was suggested that multiple daily injections would be necessary to maintain a constant buspirone blood level (Gold and Balster, 1992).

We recently reported that acute administration of relatively low doses of buspirone $(0.1$ or $0.3 \mathrm{mg} / \mathrm{kg}$, IM) selectively reduced cocaine self-administration maintained under a FR 30 schedule in rhesus monkeys (Bergman et al, 2012). Buspirone produced a downward shift in the cocaine dose-effect curve $(0.003-0.1 \mathrm{mg} / \mathrm{kg} /$ injection) with inconsistent effects on food-maintained responding (Bergman et al, 2012). The current study extends these findings to examine the effects of chronic buspirone treatment on cocaine- and food-maintained responding. Evaluation of the chronic effects of candidate treatment medications is important to determine whether tolerance develops to acute effects during repeated administration, and whether medication effects on the abused drug are sustained over time (Mello, 2005; Mello and Negus, 1996).

The present report examines the effects of 7-10 days of buspirone treatment on IV cocaine- and food-maintained responding using a procedure in which IV saline or buspirone injections were delivered every $20 \mathrm{~min}$ for $23 \mathrm{~h}$ each day. This procedure was designed to ensure that steadystate levels of the treatment medication and its metabolites were present during the four drug and food sessions each day (Negus and Mello, 2003). This procedure is especially valuable for studies of a relatively short-acting medication such as buspirone with active metabolites that may have differing durations of action (Bergman et al, 2012; Dockens et al, 2006; Gammans et al, 1986). The effects of buspirone were also studied in a conventional two-key, drug discrimination procedure to determine whether it attenuated or enhanced the cocaine discriminative stimulus.

\section{MATERIALS AND METHODS}

\section{Subjects}

Eleven male rhesus monkeys (Macaca mulatta) that weighed between 6 and $10 \mathrm{~kg}$ were studied. Each monkey was studied as his own control across saline and buspirone treatment conditions. All monkeys had a history of cocaine self-administration. Each day, monkeys received multiple vitamins, fresh fruit and vegetables, and Lab Diet Jumbo Monkey Biscuits (PMI Feeds, St Louis, MO) to supplement a banana-flavored pellet diet, fortified with vitamin C (Formula 4TUR banana flavor, grain-based pellet, Purina Mills Test Diet, Richmond, IN). Food supplements were given twice a day between 0900 and 0930 hours, and 1300 and 1330 hours. Monkeys were maintained at $90 \%$ freefeeding weight. Water was continuously available from an automatic watering system. A 12-h light-dark cycle was in effect (lights on 0800-2000 hours), and the experimental chamber was dark during food and drug self-administration sessions.

Animal maintenance and research were conducted in accordance with the guidelines provided by the Institute of Laboratory Animal Resources (ILAR-NRC, 1996) and the NIH Office of Laboratory Animal Welfare. The facility is licensed by the US Department of Agriculture, and protocols were approved by the Institutional Animal Care and Use Committee. Monkeys were observed at least twice every day, and any changes in general activity were noted. In addition, the health of the monkeys was regularly monitored by consultant veterinarians trained in primate medicine. Operant food and drug acquisition procedures provided an opportunity for enrichment and for monkeys to manipulate their environment (Line, 1987). Monkeys had visual, auditory, and olfactory contact with other monkeys throughout the study.

\section{Cocaine Self-Administration}

Surgical procedures. Double lumen Silicone rubber catheters (I.D. 0.028 in, O.D. 0.088 in) (Saint Gobain Performance Plastics, Beaverton, MI) were surgically implanted in the internal jugular, external jugular, or femoral vein to permit IV drug self-administration and IV buspirone or saline administration. All surgical procedures were performed under aseptic conditions. Monkeys were initially sedated with ketamine $(5-10 \mathrm{mg} / \mathrm{kg}$, IM), and atropine $(0.05 \mathrm{mg} / \mathrm{kg}) \mathrm{SC}$ or IM was administered to reduce salivation. Following insertion of an endotracheal tube, anesthesia was maintained with isofluorane (1-2\% mixed with oxygen). After surgery, monkeys were given procaine penicillin $\mathrm{G}$ at 20000 units $/ \mathrm{kg}$, IM twice daily for 5 days, or cephalexin $20 \mathrm{mg} / \mathrm{kg}$, PO twice daily for 5 days. An analgesic dose of buprenorphine $(0.032 \mathrm{mg} / \mathrm{kg}, \mathrm{IM})$ and Metacam (meloxicam) $(0.1 \mathrm{mg} / \mathrm{kg}, \mathrm{SC})$ was administered twice daily for 3 days.

The intravenous catheter exited in the mid-scapular region and was protected by a tether system consisting of a custom-fitted nylon vest connected to a flexible stainless-steel 
cable and fluid swivel (Lomir Biomedical, Malone, NY). This flexible tether system permits monkeys to move freely. Catheter patency was evaluated periodically by administration of a short-acting barbiturate, methohexital sodium $(4 \mathrm{mg} / \mathrm{kg})$ through the catheter lumen. If muscle tone decreased within $10 \mathrm{~s}$ after drug administration, the catheter was considered patent.

Behavioral procedures and apparatus for drug selfadministration. Monkeys lived in stainless-steel chambers $(64 \times 64 \times 79 \mathrm{~cm})$ equipped with a custom-designed operant response panel $(28 \times 28 \mathrm{~cm})$, a pellet dispenser (Gerbrands Model G5210, Arlington, MA) and two syringe pumps (Model 981210, Harvard Apparatus, South Natick, MA), one for each lumen of the double-lumen catheter. During food self-administration sessions, the response key $(6.4 \times 6.4 \mathrm{~cm})$ on the operant panel was illuminated with a red light. Completion of the response requirement under a FR 2, variable ratio 16 (FR 2, [VR 16:S]) schedule resulted in presentation of a $1 \mathrm{~s}$-red light beneath the response key. Completion of a second VR16 resulted in delivery of a 1-g banana-flavored pellet (Purina, Estherville, IA). During drug self-administration sessions, the response key was illuminated with a green light, and completion of the response requirement under a FR 2, [VR 16:S] schedule resulted in delivery of saline or a cocaine solution over $1 \mathrm{~s}$ through one lumen of the double-lumen catheter. A 10-s time-out followed delivery of each drug injection or food pellet, during which stimulus lights remained off and responding had no scheduled consequences. If 25 food pellets or 20 injections were delivered before the end of the 1-h session, then all stimulus lights were turned off, and responding had no scheduled consequences for the remainder of that session. Thus, a monkey could earn a maximum of 100food pellets/day and 80 cocaine or saline injections/day.

The four daily food self-administration sessions began at $1100,1500,1900$, and 0600 hours the next morning, and the four daily drug self-administration sessions began at 1200 , 1600,2000 , and 0700 hours the next morning. The daily sequence of sessions is shown schematically in Figure 1. Room lights were off during all experimental sessions. Schedules of reinforcement were programmed with customdesigned software and IBM-compatible computers and interface systems (Med Associates, St Albans, VT). Additional details of this apparatus have been described previously (Mello et al, 1995). Drug doses were varied by computer-controlled changes in pump infusion duration (Fivel, 2011).

Training procedure. Monkeys were initially trained to self-administer 1-g banana-flavored food pellets until foodmaintained performance was stable; subjects then were trained to respond for cocaine $(0.1 \mathrm{mg} / \mathrm{kg} /$ injection $)$. Stability was defined as at least 3 days when food- or drug-maintained responding varied by no more than 20 percent and there were no upwards or downwards trends. Once consistent cocaine-maintained responding occurred, the unit dose was reduced to 0.01 or $0.032 \mathrm{mg} / \mathrm{kg}$ to limit the disruptive effects of each IV cocaine injection, and facilitate higher levels of IV self-administration behavior throughout the session. Extinction training consisted of sessions in

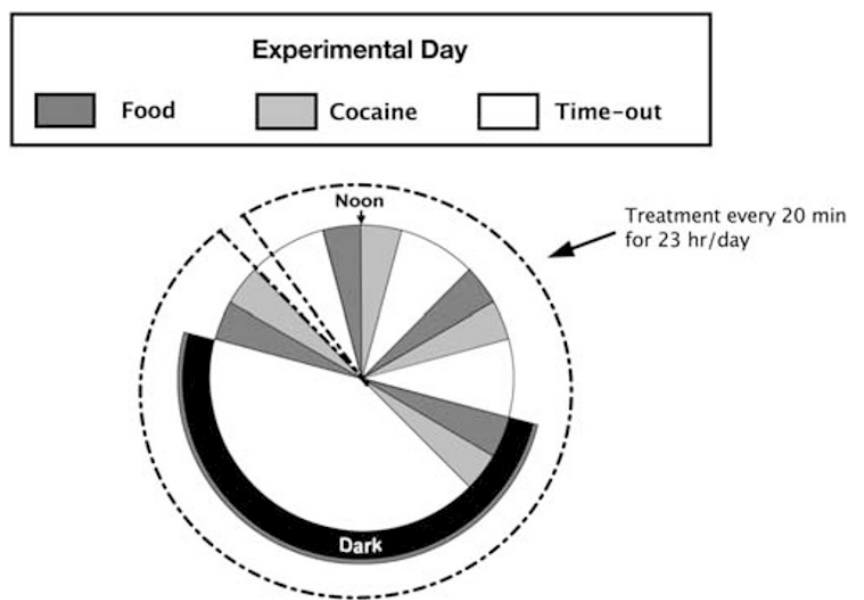

Figure I Schematic representation of daily experimental procedures. Daily food self-administration sessions are shown as black wedges. Daily cocaine self-administration sessions are shown as gray wedges. Time out periods when responding had no scheduled consequences are shown as open areas. The broken circle indicates the 23-h time period when IV buspirone or saline treatment was administered every $20 \mathrm{~min}$. The I-hour during the first time out period when daily health checks and general maintenance occurred are indicated by a break in the circle during the first morning time out. Experiments ran 7 days per week throughout the year.

which saline was substituted for the cocaine training dose. Once stable low levels of saline-maintained responding were observed during extinction, drug dose-effect curves were determined over a dose range of $0.0032-0.10 \mathrm{mg} / \mathrm{kg} /$ injection IV cocaine. Saline and different doses of cocaine were presented in an irregular order.

Cocaine dose-effect curve determinations. Training continued until monkeys met the following criteria for stable food and cocaine self-administration under the FR2 [VR16:S] schedule of reinforcement: (1) 3 consecutive days during which the number of drug injections/day varied by no more than $20 \%$ of the 3 -day mean with no upward or downward trend, and (2) the mean number of food pellets and injections delivered per day was equal to or greater than 60. Once responding was stable, saline and each dose of cocaine $(0.0032-0.10 \mathrm{mg} / \mathrm{kg} /$ injection) was substituted for a minimum of 7 days and until responding was stable according to the above criteria, or for a maximum of 10 days. Following substitution of each dose of cocaine, monkeys were returned to the maintenance dose of cocaine for at least 3 days, and until responding was stable to ensure reliable baseline responding prior to substitution of the next dose of cocaine. Cocaine doses were presented in an irregular order that differed across monkeys.

Testing procedures. Buspirone doses (0.32 and $0.56 \mathrm{mg} /$ $\mathrm{kg} / \mathrm{h}$ ) were selected on the basis of our previous report of the acute effects of buspirone (Bergman et al, 2012) and previous studies in rhesus monkeys (Gold and Balster, 1992). The effects of buspirone on the reinforcing effects of cocaine were evaluated using a procedure similar to that used in our studies of the effects of d-amphetamine on cocaine self-administration (Negus and Mello, 2003). Saline or a dose of buspirone was administered through one lumen of a double-lumen catheter every 20 minutes for $23 \mathrm{~h}$ each 
day. Buspirone treatment was suspended during 0900 and 1000 hours each morning to permit experimental changes and husbandry. This is shown schematically in Figure 1. The total injection volume delivered was $6.9 \mathrm{ml}$ in 69 injections. This medication administration procedure was developed to ensure that relatively short-acting drugs would be continuously present during the test sessions (Negus and Mello, 2003). Each treatment dose was studied for 7-10 days until responding was stable. Successive buspirone doses were separated by an interval of saline treatment until drugand food-maintained responding returned to baseline levels. The saline treatment interval was used to prevent any carryover effects from the preceding treatment.

Sedation ratings. Immediately following the noon cocaine self-administration session, sedative effects were rated on a simple scale adapted from a scale designed to measure sedation and prolactin levels following administration of a dynorphin analog (Butelman et al, 1999). These ratings were made daily by a trained observer to determine if sedation might have contributed to any changes in food or cocaine self-administration observed during buspirone treatment.

Data analysis. The primary dependent variables were the total number of cocaine or saline injections and food pellets earned per day. The number of cocaine injections selfadministered during the last 3 days of each substitution condition were averaged. A linear regression analysis was used to test for main effects of treatment and cocaine dose and a treatment $\mathrm{X}$ cocaine dose interaction for total cocaine injections and food pellets earned. Where significant main effects were found, one-way analysis of variance (ANOVA) with Dunnett's post-hoc tests were used to determine which cocaine self-administration points differed between saline and buspirone treatment doses (Sheskin, 2000). To determine which doses of cocaine produced significantly more cocaine injections compared to saline self-administration, paired $t$-tests with Bonferroni step-down error corrections were performed. All statistical procedures were accomplished using SPSS v.20 and figures were drawn using GraphPad Prism v.5.

Two of the five monkeys lost their catheters before studies of buspirone's effects on $0.0032 \mathrm{mg} / \mathrm{kg} /$ injection cocaine could be completed. Thus, each data point for saline and $0.01-0.10 \mathrm{mg} / \mathrm{kg} /$ injection cocaine (with saline and buspirone treatment) reflects 4-5 monkeys. Data for $0.0032 \mathrm{mg} / \mathrm{kg} /$ injection cocaine during buspirone treatment reflect three monkeys.

Measurement of buspirone plasma levels. Blood samples were collected from the saphenous vein in five monkeys for analysis of buspirone levels in plasma. Each monkey had $48 \mathrm{~h}$ of exposure to $0.32 \mathrm{mg} / \mathrm{kg} / \mathrm{h}$ IV buspirone before sample collection. No cocaine self-administration sessions were conducted at that time. Blood samples were collected between 0900 and 0920 hours when buspirone was not being administered (see Figure 1). Monkeys were lightly sedated with ketamine $(3-5 \mathrm{mg} / \mathrm{kg}, \mathrm{IM})$ to permit blood collection.
Plasma concentrations of buspirone were analyzed in duplicate by gas chromatography by NMS Labs, Willow Grove, PA. The assay sensitivity was $5 \mathrm{ng} / \mathrm{ml}$.

Drug source and preparation. Cocaine $\mathrm{HCl}$ was provided by the National Institute on Drug Abuse (Rockville, MD, USA) and prepared in sterile saline (0.9\%). Buspirone $\mathrm{HCl}$ was prepared in sterile water (Sigma-Aldrich, St Louis, MO, USA). Self-administered drugs were sterile-filtered with a $0.22-\mu$ syringe-driven filter.

\section{Cocaine Discrimination}

Apparatus and behavioral procedures for cocaine discrimination. Each monkey lived in a stainless-steel chamber $(56 \times 71 \times 69 \mathrm{~cm})$ equipped with a computercontrolled operant panel and food pellet dispenser. Discrimination training and testing procedures were identical to those described previously (Mello and Negus, 2007). Training sessions consisted of 1-5 cycles, and each cycle consisted of a 15-min time-out period followed by a 5 -min response period. During the time-out, all stimulus lights were off and responding had no scheduled consequences. During the response period, the right and left response keys were illuminated red or green, and monkeys could earn up to 10 food pellets under a FR 30 schedule. On training days, monkeys received saline or $0.40 \mathrm{mg} / \mathrm{kg}$ cocaine IM at the beginning of each cycle. Following saline administration, responding on only the green, salineappropriate key produced food. Following $0.40 \mathrm{mg} / \mathrm{kg}$ cocaine administration, only responding on the red, drugappropriate key produced food. Responses on the inappropriate key reset the FR requirement on the appropriate key. If the training dose of cocaine was administered, it was administered only during the last cycle. The principal dependent variables were (a) percent injection-appropriate responses for the entire cycle, and (b) response rate in responses per second. Training was complete when the following criteria were met during seven of eight consecutive training sessions: $(1) \geqslant 80 \%$ injection-appropriate responding before the first reinforcer; $(2) \geqslant 90 \%$ injectionappropriate responding for the entire cycle; $(3) \geqslant 0.5$ responses per second during saline training cycles.

The effects of acute treatment with buspirone on cocaine discrimination were studied in six monkeys. Buspirone $(0.1-0.32 \mathrm{mg} / \mathrm{kg}$, IM) was administered $15 \mathrm{~min}$ before determination of a cumulative cocaine discrimination dose-effect curve $(0.013-1.3 \mathrm{mg} / \mathrm{kg}$, IM). A control cocaine dose-effect curve was determined before each test with buspirone or saline. If responding did not meet criterion levels of discrimination performance, training was continued until criterion levels of performance occurred for at least 2 consecutive days.

Data analysis. Individual subject data are shown as cocaine-appropriate responding (over the entire response period) calculated as a percentage of responses on the cocaine lever out of total responses on the saline and cocaine levers and response rate in responses per second (excluding responses during time out) as a function of cocaine dose. Cocaine $\mathrm{ED}_{50}$ values were calculated for 
individual monkeys by log-linear interpolation as the dose of cocaine that produced $50 \%$ cocaine-appropriate responding. Data points for percentage of cocaine-appropriate responding were excluded from analysis if response rate was less than $20 \%$ of control cocaine levels for individual subjects, however, response rate data for those points are included. In pretreatment studies, buspirone was considered to alter the cocaine discrimination dose-effect curve if the test $\mathrm{ED}_{50}$ value did not fall within the $95 \%$ confidence limits of two baseline $\mathrm{ED}_{50}$ values.

\section{RESULTS}

\section{Buspirone's Effects on Cocaine Self-Administration}

When only saline was available for self-administration during saline treatment, monkeys took an average of 15.87 ( \pm 6.61 ) injections per day (Figure 2, top panel). During saline treatment, a cocaine unit dose of $0.01 \mathrm{mg} / \mathrm{kg} /$ injection was at the peak of the dose-effect curve, and monkeys selfadministered an average of $79.8( \pm 0.20)$ of a possible 80 injections per day. Figure 2 shows that treatment with buspirone $(0.32 \mathrm{mg} / \mathrm{kg} / \mathrm{h})$ for $7-10$ days shifted the ascending
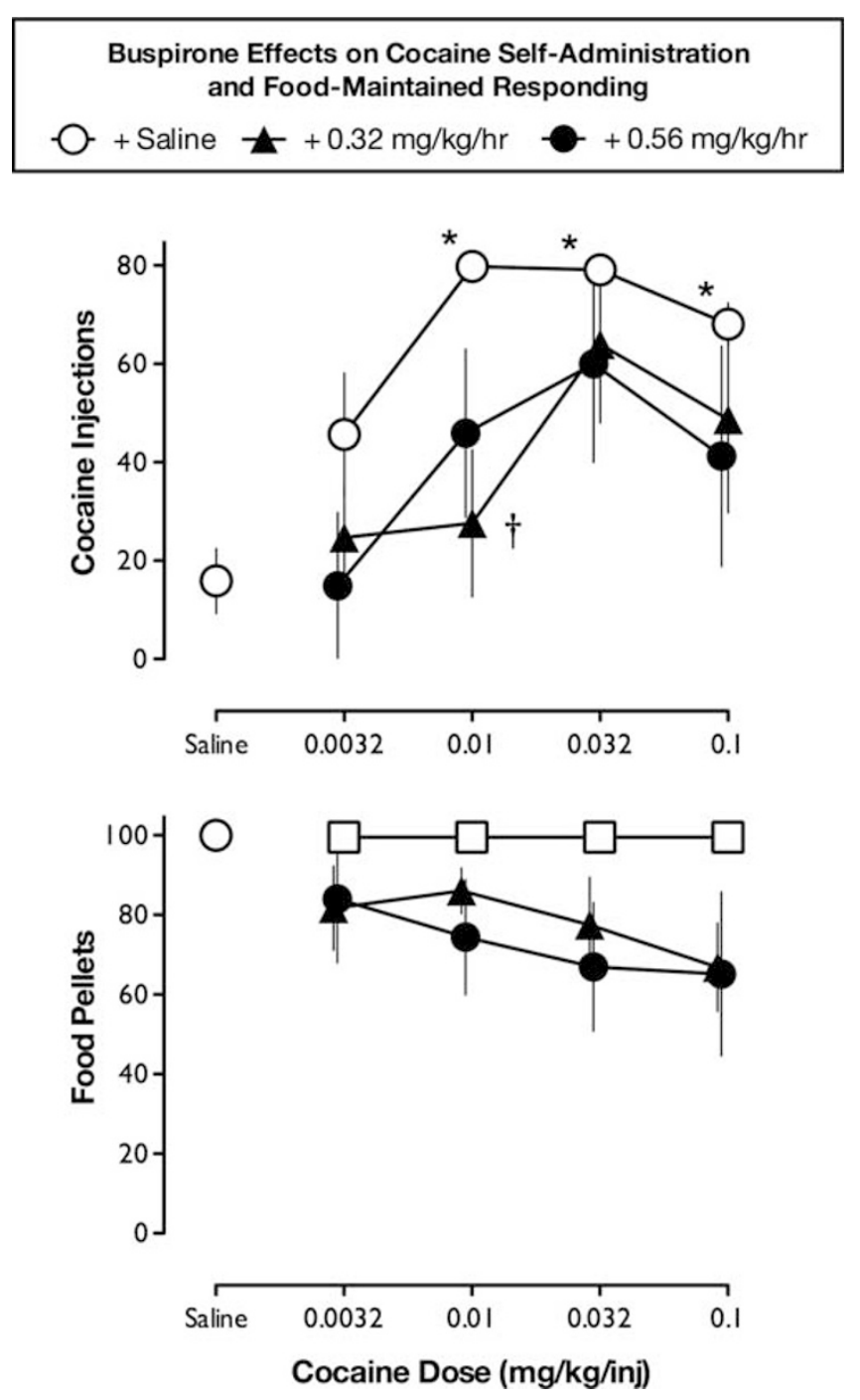

$\operatorname{limb}(0.0032 \mathrm{mg} / \mathrm{kg} /$ injection $)$ and the descending limb $(0.10 \mathrm{mg} / \mathrm{kg} /$ injection $)$ of the cocaine dose-effect curve downwards. Buspirone significantly reduced cocaine selfadministration of $0.01 \mathrm{mg} / \mathrm{kg} /$ injection, at the peak of the dose-effect curve during saline control treatment $(P<0.05)$, and shifted the peak $1 / 2 \log$ unit to the right. Treatment with a higher dose of buspirone $(0.56 \mathrm{mg} / \mathrm{kg} / \mathrm{h})$ also shifted the ascending limb of the cocaine dose-effect curve downwards. However, there were no significant differences between the effects of 0.32 and $0.56 \mathrm{mg} / \mathrm{kg} / \mathrm{h}$, buspirone on cocaine-maintained responding.

\section{Buspirone's Effects on Food-Maintained Responding}

During saline treatment and saline self-administration, monkeys took the maximum number of food pellets available (Figure 2, bottom panel). Food-maintained responding was not affected by increasing doses of cocaine during saline treatment. During treatment with 0.32 and $0.56 \mathrm{mg} / \mathrm{kg} / \mathrm{h}$ buspirone, food-maintained responding was not significantly altered on the ascending limb of the cocaine dose-effect curve when buspirone's effects on cocaine self- administration were greatest. During sessions in which cocaine unit doses of 0.01 and $0.32 \mathrm{mg} / \mathrm{kg} /$ injection were studied, treatment with $0.32 \mathrm{mg} / \mathrm{kg} / \mathrm{h}$ buspirone decreased food-maintained responding by 14 and $23 \%$, whereas treatment with $0.56 \mathrm{mg} / \mathrm{kg} / \mathrm{h}$ buspirone decreased food-maintained responding by 26 and $33 \%$. At the highest unit dose of cocaine $(0.1 \mathrm{mg} / \mathrm{kg} /$ injection $)$, food-maintained responding decreased by $33 \%$ and $34 \%$ during treatment with 0.32 and $0.56 \mathrm{mg} / \mathrm{kg} / \mathrm{h}$ buspirone, respectively.

Figure 2 The effects of chronic treatment with buspirone or saline on cocaine- and food-maintained responding. Dose-effect curves for cocaine self-administration $(0.0032-0.10 \mathrm{mg} / \mathrm{kg} /$ injection) are shown in the top panel for the group of monkeys. The unit doses of cocaine are shown on the abscissae, and the number of injections per day is shown on the left ordinate. Points above 'saline' show data from saline treatment sessions when saline was available for self-administration. Cocaine self-administration during chronic saline treatment is shown as open circles. Cocaine selfadministration during chronic treatment with buspirone is shown as filled triangles $(0.32 \mathrm{mg} / \mathrm{kg} / \mathrm{h})$ or filled circles $(0.56 \mathrm{mg} / \mathrm{kg} / \mathrm{h})$. Food-maintained responding during saline treatment and saline or cocaine self-administration is shown as open squares in the bottom panel. Food-maintained responding during treatment with buspirone is shown as filled triangles $(0.32 \mathrm{mg} / \mathrm{kg} / \mathrm{h})$ or filled circles $(0.56 \mathrm{mg} / \mathrm{kg} / \mathrm{h})$. Each data point for saline and $0.01-0.10 \mathrm{mg} / \mathrm{kg} /$ injection cocaine reflects $4-5$ monkeys. Data for $0.0032 \mathrm{mg} / \mathrm{kg} /$ injection cocaine during buspirone treatment reflect three monkeys. Each data point is based on the last 3 days of a 7- to 10-day treatment (mean $\pm \mathrm{SEM})$. The regression analysis indicated a significant main effect of treatment $(P<0.05)$ on cocaine self-administration. One-way ANOVA with Dunnett's post-test indicated that treatment with $0.32 \mathrm{mg} /$ $\mathrm{kg} / \mathrm{h}$ buspirone reduced cocaine self-administration at $0.01 \mathrm{mg} / \mathrm{kg} /$ injection $\left(F_{2,13}=4.83 ; P<0.05\right)$ and a trend for significance with $0.56 \mathrm{mg} / \mathrm{kg} / \mathrm{h}$ buspirone treatment $(P=0.076)$. Paired $t$-tests found that cocaine injections were higher than saline self-administration at doses of 0.01 , 0.032 , and $0.1 \quad(t=-9.797, \quad-9.372$, and $-6.778 ; \quad P<0.05) \mathrm{mg} / \mathrm{kg} /$ injection with saline treatment. The regression analysis on food pellets earned indicated a significant main effect of buspirone treatment $(P<0.05)$, but post-tests indicated that food-maintained responding during buspirone treatment were not significantly different from baseline at any cocaine dose. Asterisks denote data points that were significantly different from saline self-administration. Daggers indicate data points that were significantly lower than during saline control treatment. 
To further evaluate the effects of buspirone on foodmaintained responding in the absence of cocaine, data from the first food session of the experimental day were analyzed. This food session began at 1100 hours, $3 \mathrm{~h}$ after the previous
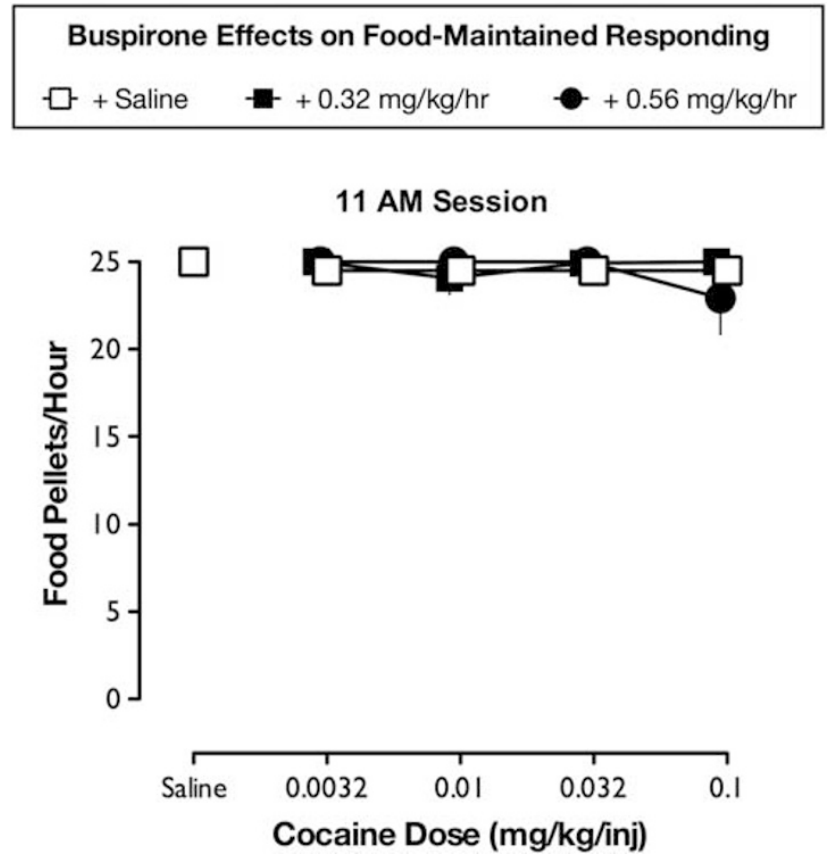

Figure 3 Effects of Buspirone on food-maintained responding in the absence of cocaine. Food-maintained responding during the 1100 hours session, $4 \mathrm{~h}$ after the last cocaine session are shown for the last 3 days of each cocaine dose condition. Saline treatment is shown as open squares, buspirone treatment is shown as black squares and black circles for doses of 0.32 and $0.56 \mathrm{mg} / \mathrm{kg} / \mathrm{h}$, respectively. The number of food pellets taken in the first food session of the experimental day is shown on the ordinate. The dose of cocaine available during that 7 - to 10-day period is shown on the abscissa. cocaine self-administration session ended at 0800 hours Figure 3 shows that monkeys self-administered the maximum number of pellets available in the session during the last 3 days of saline control and chronic buspirone treatment.

\section{Effects of Buspirone on Daily Cocaine- and Food-Maintained Responding in Representative Individual Monkeys}

During saline treatment, each monkey earned all of the cocaine injections $(0.01 \mathrm{mg} / \mathrm{kg} /$ injection $)$ and food pellets that were available each day (top row; Figure $4 \mathrm{a}$ and b). During baseline control determinations, immediately before buspirone treatment, each monkey continued to selfadminister high levels of cocaine and food.

Figure 4a (row 2) shows that initiation of buspirone treatment $(0.32 \mathrm{mg} / \mathrm{kg} / \mathrm{h})$ immediately reduced cocaine selfadministration to $34 \%$ percent of control levels and this decrease was sustained throughout 8 days of treatment. Food-maintained responding was reduced to $58 \%$ percent of control levels on day 2 of treatment, but returned to control levels on day 5. After cessation of buspirone treatment, monkey MM 30 increased cocaine self-administration to $70 \%$ percent of control levels within 4 days, but cocaine self-administration did not meet stability criteria ( 3 days of $>60$ injections) for 20 days.

The effects of treatment with a higher dose of buspirone $(0.56 \mathrm{mg} / \mathrm{kg} / \mathrm{h}$; row 3$)$ initially decreased both cocaine selfadministration and food-maintained responding to $26 \%$ and $56 \%$, respectively, on day 1 . However, cocaine selfadministration returned to control levels by day 3 and foodmaintained responding returned to control levels by day 5 . Cocaine self-administration continued to be variable for 3 days after cessation of buspirone $(0.56 \mathrm{mg} / \mathrm{kg} / \mathrm{h})$ treatment, whereas food-maintained responding remained stable.

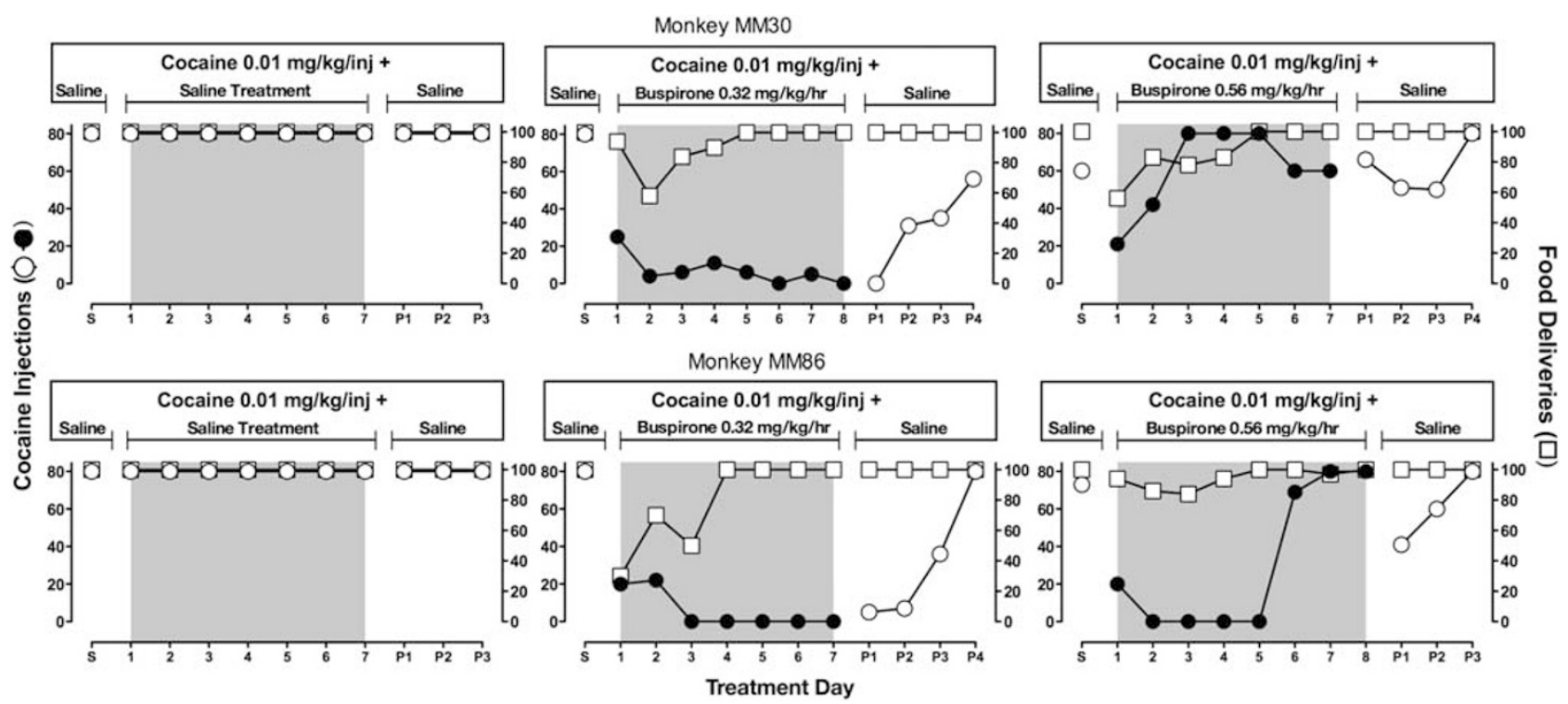

Figure 4 The effects of buspirone on cocaine- and food-maintained responding in individual monkeys (MM 30 and MM 86). Abscissae: consecutive days during and following saline (top panel) or buspirone treatment $(0.32 \mathrm{mg} / \mathrm{kg} / \mathrm{h}$; middle panel) or $(0.56 \mathrm{mg} / \mathrm{kg} / \mathrm{h}$; bottom panel). Left ordinates: number of cocaine $(0.01 \mathrm{mg} / \mathrm{kg} /$ injection) injections per day is shown as open circles during saline treatment and closed circles during $0.32 \mathrm{mg} / \mathrm{kg} / \mathrm{h}$ and $0.56 \mathrm{mg} / \mathrm{kg} / \mathrm{h}$ buspirone treatment. Right ordinates: number of food pellets $(\mathrm{I}$ g) earned per day is shown as open squares. Points above saline (S) in each panel show the mean number of injections/day and food pellets/day during 3 days of saline treatment baseline control conditions (mean + SEM). 

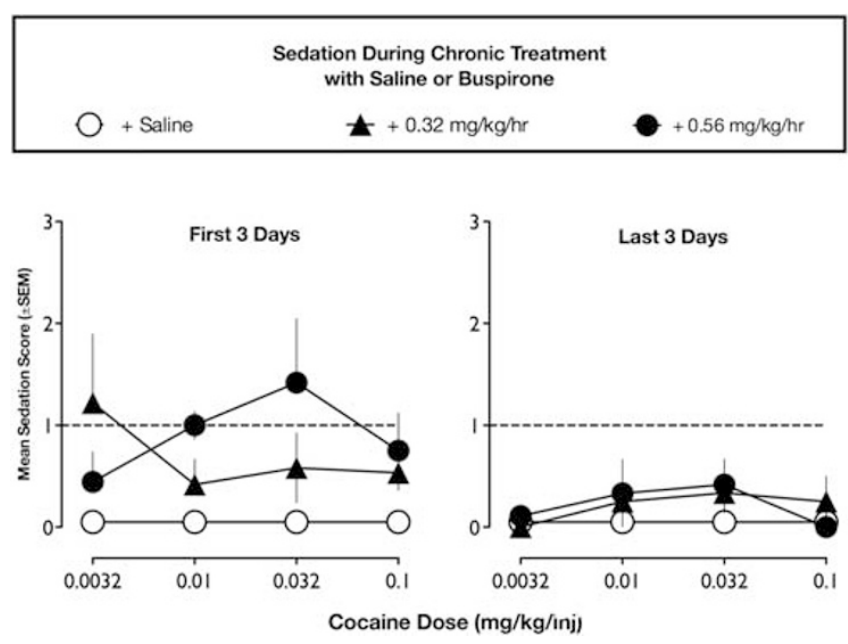

Figure 5 Sedation ratings during chronic buspirone treatment and cocaine self-administration. Cocaine unit doses are shown on the abscissae, and sedation scale ratings immediately following the noon cocaine selfadministration session are shown on the left ordinates. Sedation was scored as: $0=$ no observable sedation; alert to environment; I = mildly sedated, quieter than usual, but reaches for food treats; $2=$ moderately sedated, does not reach for food treats but does respond to noise in the room; $3=$ heavily sedated, lying on floor of cage, no response to experimenter. Sedation ratings during chronic treatment with saline (open circles), 0.32 (filled triangles), and 0.56 (filled circles) $\mathrm{mg} / \mathrm{kg} / \mathrm{h}$ buspirone are shown during the first 3 days of treatment (left panel) and during the last 3 days of treatment (right panel). Each data point for saline and $0.01-0.10 \mathrm{mg} / \mathrm{kg} /$ injection cocaine reflects 4-5 monkeys. Data for $0.0032 \mathrm{mg} / \mathrm{kg} /$ injection cocaine during buspirone treatment reflect three monkeys.

Figure $4 \mathrm{~b}$ (row 2) shows that cocaine self-administration decreased to about $25 \%$ of control levels when treatment with $0.32 \mathrm{mg} / \mathrm{kg} / \mathrm{h}$ buspirone was initiated. Subsequently, cocaine self-administration was completely abolished on treatment days 3-7. Food-maintained responding was also initially reduced to about $30 \%$ of control levels but returned to baseline within 4 days. When treatment with a higher dose of buspirone $(0.56 \mathrm{mg} / \mathrm{kg} / \mathrm{h})$ began, cocaine selfadministration immediately fell to $25 \%$ of control levels and remained low for 5 days (Figure 2b, row 3 ). On days 6 , 7 , and 8 , cocaine self-administration returned to control levels. Upon cessation of buspirone treatment, cocaine selfadministration fell to about $50 \%$ of control levels then returned to baseline by days 3 and 4. Food-maintained responding was minimally affected during or after buspirone treatment.

\section{Recovery of Cocaine Self-Administration and Food-Maintained Responding After Buspirone Treatment}

After saline treatment, monkeys usually met stability criteria within 3 days. However, at the lowest dose of cocaine $(0.0032 \mathrm{mg} / \mathrm{kg} /$ injection), monkeys took an average of $8.0( \pm 2.88)$ days to reach stability after saline treatment (Figure $4 \mathrm{a}$ and $\mathrm{b}$ ). At the highest cocaine dose studied $(0.1 \mathrm{mg} / \mathrm{kg} /$ injection), recovery was more rapid and took an average of $5.6 \pm 1.78$ days. When $0.32 \mathrm{mg} / \mathrm{kg} / \mathrm{h}$ buspirone was discontinued, recovery of cocaine self-administration increased by an average of $4.4( \pm 2.42)$ days and ranged from 2 to 26 days. The increase in days to reach stability was consistent across all cocaine doses. When $0.56 \mathrm{mg} / \mathrm{kg} / \mathrm{h}$ buspirone was discontinued, recovery of cocaine selfadministration increased by an average of $2.38( \pm 2.55)$ days. Food-maintained responding was not disrupted at any cocaine dose during saline treatment and all monkeys met stability criteria within 3 days post-treatment. Although a slight decrease in food-maintained responding was evident during treatment with 0.32 and $0.56 \mathrm{mg} / \mathrm{kg} / \mathrm{h}$ buspirone treatment (see Figure 3), food-maintained responding recovered almost immediately after treatment cessation.

\section{Buspirone Plasma Levels}

After $48 \mathrm{~h}$ of exposure to $0.32 \mathrm{mg} / \mathrm{kg} / \mathrm{h}$, IV buspirone, in the absence of concurrent cocaine self-administration, buspirone plasma levels averaged $60.2 \pm 6.85 \mathrm{ng} / \mathrm{ml}$. The buspirone plasma values ranged from 39 to $74 \mathrm{ng} / \mathrm{ml}$.

\section{Buspirone's Side Effects and Safety During Chronic Treatment}

Ratings of buspirone's sedative effects, recorded immediately following the noon cocaine self-administration sessions, are shown in Figure 5. Data are shown for the first 3 days after buspirone treatment began (left panel), and for the last 3 days before the treatment was terminated (right panel). There were minimal sedative effects immediately following each noon cocaine self-administration session. Monkeys were alert, responsive to the investigator, and would take food treats. During buspirone treatment $(0.32 \mathrm{mg} / \mathrm{kg} / \mathrm{h})$, sedation scores indicated either mild sedation or no sedation. At the higher dose of buspirone, only one monkey was heavily sedated, and all other scores indicated either mild (1) or no sedation (0) at all doses of cocaine. In general, sedative effects with the higher dose of buspirone treatment were lower during the last 3 days than during the first 3 days of treatment.

\section{Buspirone's Effects on Cocaine Discrimination}

During the training days preceding test days, monkeys responded exclusively on the saline key during saline cycles and almost exclusively on the cocaine key $(99.95 \% \pm 0.05)$ during cocaine cycles. Mean response rates $( \pm$ SEM) were $2.40( \pm 0.44)$ and $2.18( \pm 0.50)$ responses per second during saline and cocaine training cycles, respectively. Control data for each individual monkey are shown in the shaded areas in Figure 6 (for discriminative stimulus effects) and Figure 7 (for response rates). Figures 6 and 7 show the discriminative stimulus and rate-altering effects of cocaine administered alone or $15 \mathrm{~min}$ after pretreatment with buspirone $(0.1-0.32 \mathrm{mg} / \mathrm{kg})$. All monkeys showed dose-dependent increases in cocaine-like responding during baseline cumulative cocaine tests. $\mathrm{ED}_{50}$ values for cocaine discrimination in individual monkeys are shown in Table 1. In three monkeys (89B013, A056, and CH599), buspirone produced a significant rightward shift in the cocaine discrimination dose-effect curve. All monkeys responded at or near 100\% at the training dose of cocaine $(0.4 \mathrm{mg} / \mathrm{kg})$ during baseline conditions. Buspirone pretreatment reduced cocaine-like responding in four monkeys (89B013, A056, RQ1499, and CH599). The highest dose of buspirone $(0.32 \mathrm{mg} / \mathrm{kg})$ also 


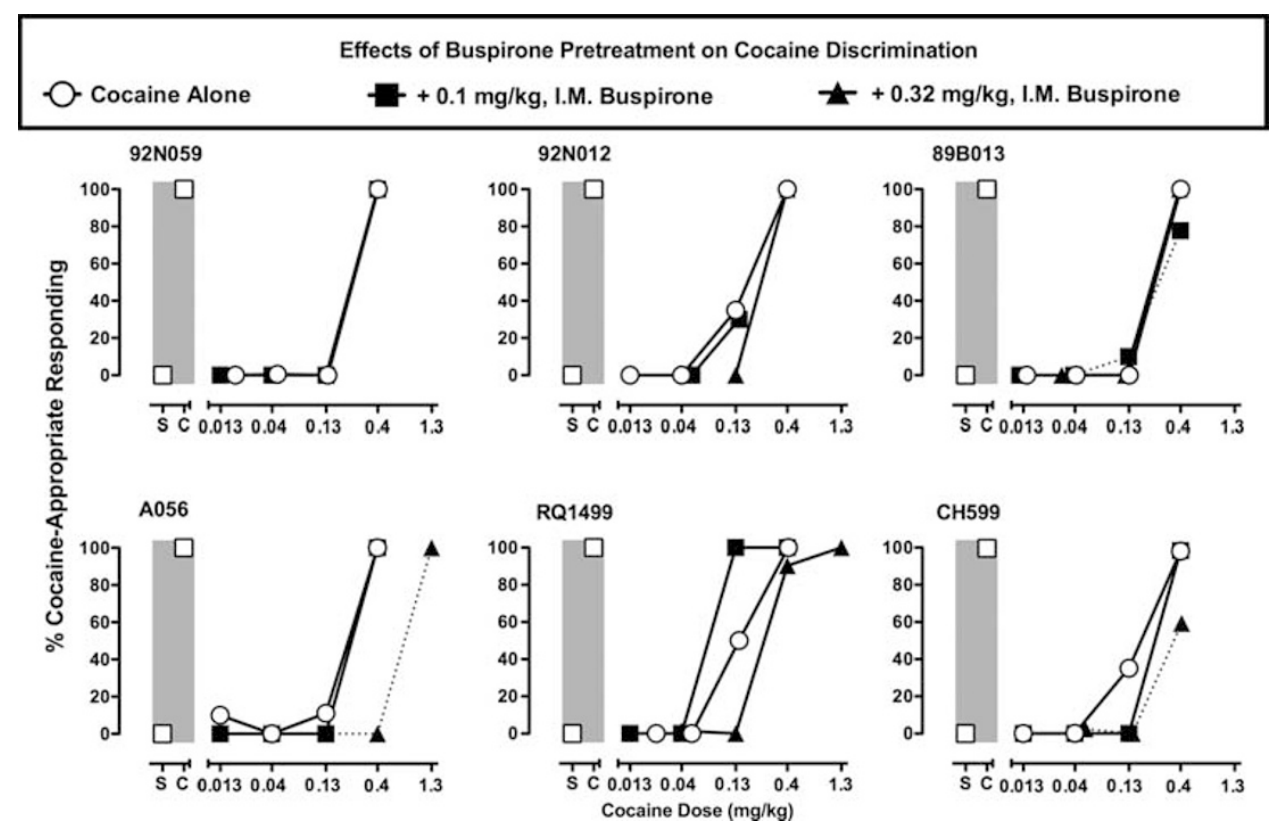

Figure 6 Discriminative stimulus effects of cocaine administered alone or $15 \mathrm{~min}$ after pretreatment with buspirone $(0.1 \mathrm{or} 0.32 \mathrm{mg} / \mathrm{kg}$, IM). Abscissae: dose of cocaine in $\mathrm{mg} / \mathrm{kg}$ (log scale). Ordinates: \% cocaine-appropriate responding for the entire session. Points above ' $\mathrm{S}$ ' and ' $\mathrm{C}$ ' show control data obtained during saline and cocaine training cycles, respectively. Dose-effect curves for 'cocaine alone' show mean data from two determinations in each monkey, Dose-effect curves for cocaine + buspirone show data from one determination in each monkey. Dashed connecting lines indicate dose-effect curves with significantly greater $\mathrm{ED}_{50}$ values compared with 'cocaine alone'.

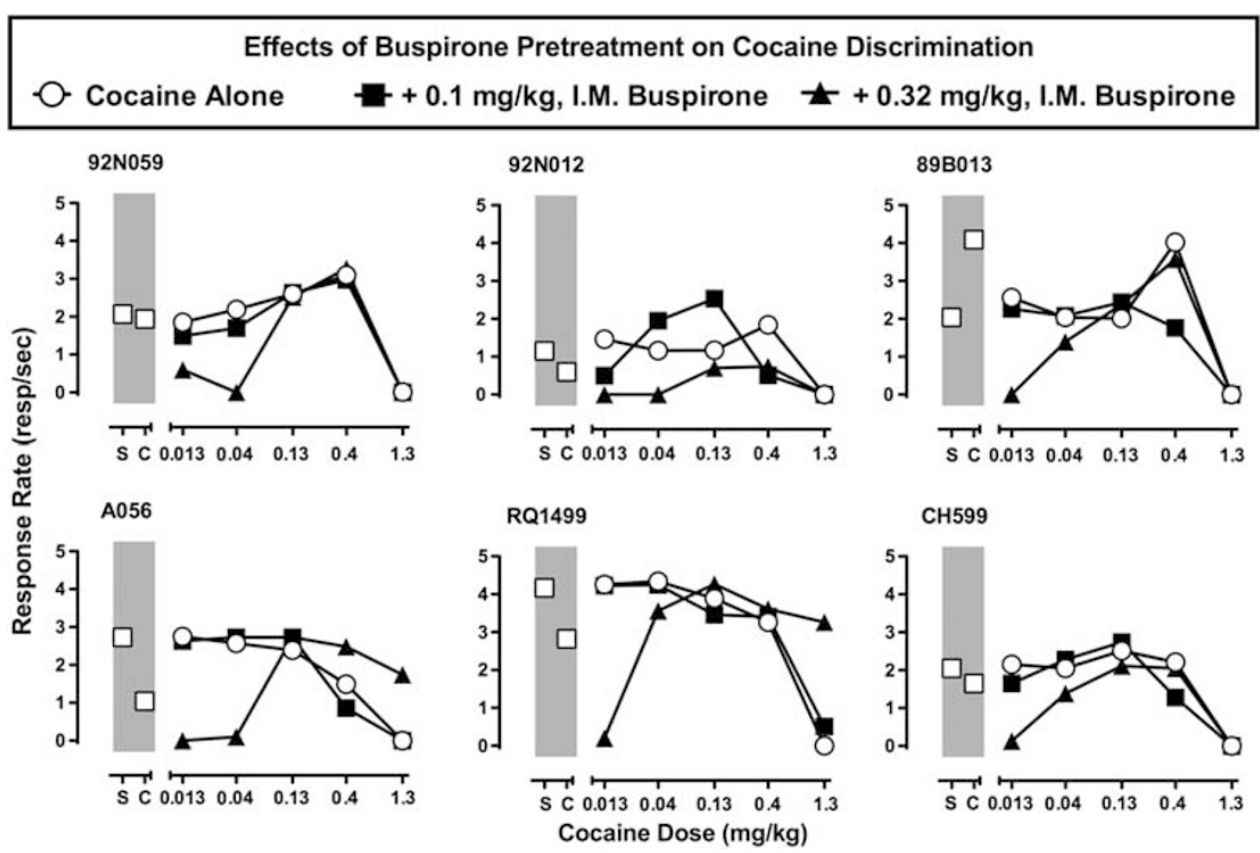

Figure 7 Rate-altering effects of cocaine administered alone or after pretreatment with buspirone: abscissae: dose cocaine in mg/kg (log scale). Ordinates: response rate in responses per second. Points above ' $\mathrm{S}$ ' and ' $\mathrm{C}$ ' show control data obtained during saline and cocaine training cycles, respectively. Doseeffect curves for 'cocaine alone' show mean data from two determinations in each monkey. Dose-effect curves for cocaine + buspirone show data from one determination in each monkey.

attenuated the rate-decreasing effects of the highest dose of $1.3 \mathrm{mg} / \mathrm{kg}$ cocaine in two of those monkeys.

In contrast to drug self-administration studies where buspirone was administered every $20 \mathrm{~min}$ as $\mathrm{mg} / \mathrm{kg} / \mathrm{h}$, a single bolus IM dose in drug discrimination produced significant sedative effects. During the first two cycles of cumulative cocaine tests, buspirone $(0.32 \mathrm{mg} / \mathrm{kg}, \mathrm{IM})$ produced dose-dependent decreases in response rates, overt catalepsy-like behavior, and monkeys were unresponsive to approach of investigator. These rate-decreasing and catalepsy-like effects dissipated during later cycles (about 4565 min after buspirone administration). Buspirone's transient 
Table I ED 50 Values $(\mathrm{mg} / \mathrm{kg}$ ) of Cocaine Alone (95\% confidence intervals) and in Combination with Buspirone for Substituting for Cocaine Drug Discrimination

\begin{tabular}{lccc}
\hline ID & Cocaine alone & $\begin{array}{c}+\mathbf{0 . 1} \mathbf{~ m g} / \mathbf{k g} \\
\text { Buspirone }\end{array}$ & $\begin{array}{c}+\mathbf{0 . 3 2} \mathbf{~ m g} / \mathbf{k g} \\
\text { Buspirone }\end{array}$ \\
\hline RQ1499 & $0.13(0.04-0.40)$ & 0.07 & 0.24 \\
92N059 & $0.23(0.23-0.23)$ & 0.23 & 0.23 \\
A056 & $0.19(0.13-0.27)$ & 0.23 & $0.72^{\mathrm{a}}$ \\
92N012 & $0.16(0.08-0.32)$ & 0.29 & 0.23 \\
CH599 & $0.16(0.08-0.33)$ & 0.23 & $0.34^{\mathrm{a}}$ \\
89B013 & $0.23(0.23-0.23)$ & $0.25^{\mathrm{a}}$ & 0.23 \\
\hline
\end{tabular}

${ }^{\mathrm{a}}$ Denotes $\mathrm{ED}_{50}$ values after buspirone fell outside of the $95 \%$ confidence intervals of baseline $\mathrm{ED}_{50}$ values.

disruption of behavior may indicate that these effects were attenuated by increasing cumulative doses of cocaine, or may reflect buspirone's relatively short duration of action.

\section{DISCUSSION}

This report describes the effects of chronic buspirone treatment on the reinforcing effects of cocaine. These findings confirm and extend our previous findings that acute doses of buspirone dose-dependently reduced cocaine self-administration by nonhuman primates (Bergman et al, 2012). Buspirone was selected for study, in part, because it is FDA approved for the treatment of anxiety. Our finding that chronic buspirone can selectively reduce cocaine selfadministration by rhesus monkeys may have important clinical implications. The preclinical IV drug self-administration model used in this study has good predictive validity for drug abuse treatment medications that are clinically available (Mello, 2005).

The relation of our data to previous reports of the interactions between buspirone and cocaine in drug selfadministration and drug discrimination studies are described below. Possible receptor mechanisms contributing to buspirone's effects on cocaine-maintained responding are discussed. Buspirone's dopamine $\mathrm{D}_{2}, \mathrm{D}_{3}$, and $\mathrm{D}_{4}$ receptor activity are examined in the context of recent discoveries of the potential role of $\mathrm{D}_{3}$ antagonists and partial agonists in modulating cocaine's abuse-related effects. Some strengths, limitations, and translational implications of this study are also described.

\section{Buspirone's Effects on Cocaine Self-Administration}

Our results using a chronic buspirone treatment paradigm are consistent with our previous study of the acute effects of buspirone on cocaine self-administration (Bergman et al, 2012), and overlap with data from previous studies in rhesus monkeys (Gold and Balster, 1992). A single high dose of buspirone $(1.0 \mathrm{mg} / \mathrm{kg}$, IV) administered $15 \mathrm{~min}$ before a 1-h cocaine self-administration session, decreased cocainemaintained responding, whereas acute or repeated administration of lower doses $(0.1-0.56 \mathrm{mg} / \mathrm{kg}$, IV) had no effect or increased responding (Gold and Balster, 1992). It was suggested that buspirone's relatively short duration of action may have contributed to the observed lack of effect on cocaine self-administration (Gold and Balster, 1992). In the present study, IV buspirone was administered every $20 \mathrm{~min}$ for $23 \mathrm{~h}$ each day for 7-10 days to insure that significant levels of buspirone and its metabolites were present throughout each food and cocaine self-administration session conducted between 1100 and 2000 hours each day (see Figure 1). Our current findings suggest that $0.32 \mathrm{mg} / \mathrm{kg} / \mathrm{h}$ buspirone is sufficient to selectively reduce cocaine self-administration by rhesus monkeys, and a slightly higher dose of buspirone is not more effective.

In the present study, buspirone $(0.32$ and $0.56 \mathrm{mg} / \mathrm{kg} / \mathrm{h}) \mathrm{did}$ not enhance the stimulant effects of cocaine over a dose range of $0.0032-0.10 \mathrm{mg} / \mathrm{kg} /$ injection. However, in squirrel monkeys, buspirone- $(0.001-0.03 \mathrm{mg} / \mathrm{kg})$ related increases in cocaine-maintained responding were observed under a second-order schedule (Nader and Barrett, 1990). It is likely that this reflected disruptions in responding rather than direct stimulant effects of buspirone because IV cocaine was not given until the end of the session (Nader and Barrett, 1990). In rats, buspirone's effects on cocaine self-administration varied as a function of the schedule of reinforcement (Homberg et al, 2004). Buspirone (1.25 and $2.5 \mathrm{mg} / \mathrm{kg}$ ) significantly reduced cocaine self-administration maintained on a progressive ratio schedule, but increased cocaine selfadministration when the response requirement was low (FR1) (Homberg et al, 2004). Similar effects have been reported for $\mathrm{D}_{3}$ selective antagonist and partial agonist treatment of cocaine self-administration in rats (Gal and Gyertyan, 2003; Gyertyan et al, 2007; Heidbreder et al, 2005).

\section{Buspirone's Effects on Cocaine Discrimination}

There has been relatively little attention to the effects of buspirone on cocaine discrimination. In the present study, buspirone $(0.1$ and $0.32 \mathrm{mg} / \mathrm{kg}, \mathrm{IM})$ did not consistently alter the discriminative stimulus and rate-altering effects of cocaine, and similar findings have been reported in rats (Rapoza, 1993). We interpret these data to suggest that monkeys were able to recognize cocaine, even after relatively high acute doses of buspirone. However, these data are not concordant with previous findings in rats trained to discriminate cocaine $(5 \mathrm{mg} / \mathrm{kg}$, IM) from saline (Callahan and Cunningham, 1997). In that study, buspirone $(2.5-20 \mathrm{mg} / \mathrm{kg})$ dose-dependently reduced cocaine discrimination and shifted the cocaine dose-effect function to the right (Callahan and Cunningham, 1997). A combination of procedural and species differences may have contributed to these discrepant findings. In rhesus monkeys trained to discriminate cocaine $(0.1 \mathrm{mg} / \mathrm{kg}, \mathrm{IV})$ from saline, buspirone $(0.03-0.56 \mathrm{mg} / \mathrm{kg}, \mathrm{IV})$ did not substitute for cocaine, but the effects of buspirone pretreatment were not tested (Koetzner, 1996). The finding that buspirone did not substitute for cocaine (Koetzner, 1996) is consistent with reports that buspirone does not maintain self-administration in rhesus monkeys and baboons, and has low abuse potential (Balster, 1990; Balster and Woolverton, 1982; Griffiths et al, 1991).

\section{Buspirone's Receptor Mechanisms}

The mechanisms by which buspirone selectively reduces cocaine self-administration by rhesus monkeys are unclear, 
and probably reflect an interaction between dopamine and $5-\mathrm{HT}_{1 \mathrm{~A}}$ receptors. Recent radioligand-binding studies indicated that buspirone has high affinity for dopamine $\mathrm{D}_{3}$ and $\mathrm{D}_{4}$ receptors, as well as for $\mathrm{D}_{2}$ receptors (Bergman et al, 2012). The functional activity of buspirone also was examined in live cell $\beta$-Arrestin assays. It was found that buspirone had no agonist activity, and antagonized dopamine activation of $\mathrm{D}_{3}$ and $\mathrm{D}_{4}$ receptors with similar potencies. We concluded that buspirone was a functional antagonist at $\mathrm{D}_{2}$-like dopamine receptors with the highest affinity/potency for the $\mathrm{D}_{3}$ and $\mathrm{D}_{4}$ receptor subtypes (Bergman et al, 2012). These findings were consistent with earlier radioligand-binding studies of buspirone (Kula et al, 1994; Tallman et al, 1997).

Although the present study does not permit a clear distinction between the role of $\mathrm{D}_{2}, \mathrm{D}_{3}$, and $\mathrm{D}_{4}$ receptors in buspirone's effects on cocaine self-administration, it may be useful to review recent evidence concerning buspirone's $\mathrm{D}_{2}$, $\mathrm{D}_{3}$, and $\mathrm{D}_{4}$ activity. Many investigators have concluded that buspirone's behavioral effects are primarily mediated through $\mathrm{D}_{2}$ antagonist actions (Callahan and Cunningham, 1997; Rijnders and Slangen, 1993). This conclusion is usually based on the similarity between the effects of buspirone and other known $\mathrm{D}_{2}$ antagonists. For example, buspirone's effects were similar to those of haloperidol and supiride in drug discrimination studies in rats (Rijnders and Slangen, 1993). In addition, the finding that gepirone, a selective $5-\mathrm{HT}_{1 \mathrm{~A}}$ partial agonist, did not affect cocaine's discriminative stimulus effects in rats was interpreted to suggest that buspirone's reduction of cocaine's discriminative stimulus effects primarily reflected its $\mathrm{D}_{2}$ antagonist properties and not its $5-\mathrm{HT}_{1 \mathrm{~A}}$ agonist effects (Callahan and Cunningham, 1997). Gepirone also failed to alter cocaine self-administration by rhesus monkeys (Gold and Balster, 1992). Nonetheless, an influence of $5-\mathrm{HT}_{1 \mathrm{~A}}$ receptors on stimulant abuse is possible, and may involve complex preand post-synaptic actions (Muller et al, 2007).

An emerging literature attests to the potential importance of dopamine $\mathrm{D}_{3}$ and $\mathrm{D}_{4}$ receptors activity in the modulation of cocaine's abuse-related effects (see for review Heidbreder et al, 2005; Heidbreder and Newman, 2010; Le Foll et al, 2005; Le Foll et al, 2000; Newman et al, 2005; Newman et al, 2012). Dopamine $D_{3}$ receptor agonists, antagonists, and partial agonists each can influence the behavioral effects of cocaine under some conditions. However, the relative effectiveness of $\mathrm{D}_{3}$ receptor partial agonists and antagonists for reducing the abuse-related effects of cocaine remains unresolved. $\mathrm{D}_{3}$ selective agonists produced cocaine-like effects in rhesus and squirrel monkeys, and in rats trained to discriminate cocaine from saline (Achat-Mendes et al, 2010; Acri et al, 1995; Lamas et al, 1996; Spealman, 1996). $\mathrm{D}_{3}$ selective agonists also maintained self-administration in rats (Caine and Koob, 1993) and rhesus monkeys (Nader and Mach, 1996). Consistent with clinical reports that agonist therapies are effective in reducing cocaine abuse (Herin et al, 2010), the $\mathrm{D}_{3}$ preferring agonists, such as 7-OH-DPAT, also have been shown to reduce cocaine self-administration by rats (Caine and Koob, 1995).

Like $D_{3}$ receptor agonists, $D_{3}$ receptor antagonists also decrease cocaine self-administration under several behavioral procedures in rhesus monkeys, but do not appear to have abuse potential. Novel $\mathrm{D}_{3}$ antagonists and partial agonists each attenuated the reinforcing and discriminative stimulus effects of cocaine under some conditions in rhesus monkeys (Beardsley et al, 2001; Claytor et al, 2006; Martelle et al, 2007; Nader et al, 1999). In contrast, in squirrel monkeys, a $\mathrm{D}_{3}$ partial agonist and a $\mathrm{D}_{3}$ antagonist did not alter cocaine self-administration (Achat-Mendes et al, 2010; Achat-Mendes et al, 2009). In comparison, a $\mathrm{D}_{2}$ antagonist, studied under the same conditions, decreased cocaine selfadministration and cocaine discrimination, and cocaineinduced reinstatement (Achat-Mendes et al, 2010). In a reinstatement paradigm, $\mathrm{D}_{3}$ and $\mathrm{D}_{2}$ agonists dose-dependently reinstated cocaine seeking and $\mathrm{D}_{3}$ and $\mathrm{D}_{2}$ antagonists attenuated cocaine reinstatement (Achat-Mendes et al, 2010).

In rats, selective dopamine $\mathrm{D}_{3}$ receptor antagonists (SB$27701_{1 \mathrm{~A}}$ and NGB 2904) reduced cocaine self-administration maintained on a progressive ratio schedule, and significantly lowered progressive ratio breakpoints (Xi et al, 2005; $\mathrm{Xi}$ et al, 2006); see for review Xi and Gardner, 2007). Direct infusion of SB-27701 $1 \mathrm{~A}$ into the basolateral amygdala (but not the nucleus accumbens shell or dorsal striatum) also reduced cocaine self-administration maintained on a second-order schedule (Di Ciano, 2008). Selective $D_{3}$ receptor partial agonists (RGH-237) blocked cue-induced reinstatement of cocaine seeking, but had no effect on sucrose or water seeking (Gyertyan et al 2007). A number of investigators have reported that $D_{3}$ selective compounds have no effect on cocaine self-administration maintained on a low-response requirement, such as a FR 1 schedule (Gyertyan et al, 2007; Pilla et al, 1999; Xi and Gardner, 2007; see for review Heidbreder et al, 2005), but are effective at higher response requirements (eg, FR 10 and progressive ratio schedules) (Xi and Gardner, 2007; Xi et al, 2005). Selective $\mathrm{D}_{3}$ receptor antagonists also inhibited cocaineinduced reinstatement (Gyertyan et al, 2007), biphasically increased and decreased cocaine self-administration maintained on a FR schedule (Gyertyan et al, 2007), and reduced cocaine-enhanced brain stimulation (Peng et al, 2009). A $\mathrm{D}_{3}$ receptor antagonist reduced cocaine self-administration maintained on both fixed and progressive ratio schedule in rats and mice (Song et al, 2012). Interestingly, a $\mathrm{D}_{3}$ antagonist did not inhibit cocaine self-administration in $\mathrm{D}_{3}$ receptor knockout mice (Song et al, 2012). Taken together, these data illustrate that the response requirement is a critical determinant of dopamine $\mathrm{D}_{3}$ receptor effects on the abuse-related effects of cocaine.

\section{Strengths and Limitations of the Study}

This evaluation of chronic daily buspirone treatment was designed to model clinical treatment trials. An important strength of this study is that treatment effects on both foodand cocaine-maintained responding were studied. This procedure facilitates evaluation of the extent to which the effects of a treatment drug are selective for cocaine or reduces both food- and cocaine-maintained responding, indicating a general disruption of operant responding. We conclude that the sustained decreases in cocaine selfadministration reflected the effects of buspirone treatment and not other confounding factors for the following reasons: (1) there was no evidence of catheter malfunction because all monkeys resumed cocaine self-administration at saline 
treatment baseline levels after buspirone treatment; (2) decreases in cocaine self-administration were not associated with sedative effects that interfered with operant responding; (3) buspirone, across the dose range studied on cocaine self-administration, did not produce catatonia or other adverse behavioral effects; (4) buspirone's effects were selective for cocaine and had modest initial effects on foodmaintained responding that usually dissipated during the course of treatment. Moreover, this is the first study in which buspirone was administered intermittently (every $20 \mathrm{~min}$ for $23 \mathrm{~h}$ ) throughout each day to insure that doses were stable during food and cocaine sessions. Finally, the same monkeys were studied as their own control across successive treatment conditions to minimize any influence of idiosyncratic individual reactions.

One possible limitation of this study is that buspirone doses used clinically for the treatment of anxiety are usually lower than the dose necessary to reduce cocaine selfadministration by rhesus monkeys $(0.32 \mathrm{mg} / \mathrm{kg} / \mathrm{h})$. After oral administration, the usual clinical dose of buspirone (20-40 mg in divided doses) reached maximum concentrations within $1 \mathrm{~h}$ and the elimination half-life was about $2.5 \mathrm{~h}$ (Gammans et al, 1986; Goldberg, 1984; Mahmood and Sahajwalla, 1999; Mandrioli and Mercolini, 2010). In a clinical trial to evaluate the effectiveness of buspirone for prevention of relapse to cocaine, oral doses of $60 \mathrm{mg} /$ day are planned (Winhusen et al, 2012).

There has been relatively little attention to the pharmacokinetics of buspirone in rhesus monkeys. Two reports conclude that the pharmacokinetics of buspirone appear to be similar in humans and in rhesus monkeys (Gammans et al, 1986; Marathe et al, 1999). For example, plasma concentrations of C14 labeled buspirone were similar over $1 \mathrm{~h}$ (Gammans et al, 1986). When rhesus monkeys were given repeated oral doses of buspirone $(12.5,25$ and $50 \mathrm{mg} /$ $\mathrm{kg}$ /day), the peak levels $\left(C_{\max }\right)$ were dose dependent, but there was considerable variability between animals (Marathe et al, 1999). We also observed considerable variability between animals in plasma buspirone levels after repeated IV doses for $48 \mathrm{~h}(0.32 \mathrm{mg} / \mathrm{kg} / \mathrm{h})$. Although the plasma levels in rhesus monkeys ranged from 39 to $74 \mathrm{ng} /$ $\mathrm{ml}$, it is important to note that there were no adverse behavioral or medical consequences of chronic buspirone treatment. There were no significant changes in blood chemistry assessments at $3,4,10$, or 14 days after discontinuation of buspirone. Differences in the route (oral $v s$ IV) and rate (bolus $v s$ three injections per hour) of buspirone administration in humans and rhesus monkeys as well as differences in analytic procedures (gas chromatography, radioimmunoassay) make it difficult to compare effective doses.

\section{Translational Implications of Buspirone's Reduction of Cocaine Self-Administration by Rhesus Monkeys}

Evaluations of candidate medications in this preclinical drug self-administration model have shown good concordance with clinical treatment trials (Mello, 2005). This model is valuable for medication development, because often candidate treatment drugs are not FDA approved for evaluation in humans. The reliability and predictive validity of this model has been repeatedly demonstrated (see for review Haney and
Spealman, 2008; Mello, 2005; Mello and Negus, 1996). An optimal treatment medication would have low abuse liability and minimal side effects in addition to selective reduction of the abuse-related effects of the target drug of abuse. Buspirone appears to have no abuse liability in rhesus monkeys (Balster, 1990) and, despite its putative anxiolytic effects, increased tension, nervousness, and dysphoria were reported in clinical laboratory studies (Cole, 1982; Griffith et al, 1986; Rush et al, 1995). Chronic buspirone treatment produced only mild and transient sedation in rhesus monkeys in the present study, and did not increase ratings of drowsy or sleepy in humans (Rush et al, 1995). It is possible that the combination of dopamine antagonism and $5-\mathrm{HT}_{1 \mathrm{~A}}$ effects may be valuable in the development of medications for cocaine abuse. Some side effects usually observed during treatment with dopamine $D_{2}$ receptor antagonists (catatonia, catalepsy) were not observed during buspirone treatment and cocaine self-administration. This observation is consistent with an extensive literature showing that $5-\mathrm{HT}_{1 \mathrm{~A}}$ agonists, including buspirone, attenuate dopamine $\mathrm{D}_{2}$-induced catalepsy (Kleven et al, 2005; Prinssen et al, 2002; Prinssen et al, 2000).

In summary, the present study indicates that chronic buspirone treatment reduced IV cocaine self-administration by nonhuman primates. Although it is unlikely that a single drug will be effective in all individuals, if buspirone proves to be as effective in clinical settings as in the preclinical laboratory, it will be a useful addition to the current treatment options for cocaine abuse. Although the relative contribution of buspirone's $5-\mathrm{HT}_{1 \mathrm{~A}}$ and dopamine $\mathrm{D}_{2}, \mathrm{D}_{3}$, and $\mathrm{D}_{4}$ activity remains to be determined, buspirone has the important advantage of FDA approval for clinical use for another indication. Basic research to clarify the effects of 5$\mathrm{HT}_{1 \mathrm{~A}}$ and dopamine receptor subtypes on the abuse-related effects of cocaine are urgently needed to optimize such strategies for medication development.

\section{ACKNOWLEDGEMENTS}

This work was supported in part by grant number R01DA002519 and R01-DA026892 (NK Mello, PI) from the National Institute on Drug Abuse, NIH. We thank Meredith Mahnke, Sherilyn Pattel, and Olga Smirnova for excellent technical assistance.

\section{DISCLOSURE}

The authors declare no conflict of interest.

\section{REFERENCES}

Achat-Mendes C, Grundt P, Cao J, Platt DM, Newman AH, Spealman RD (2010). Dopamine D3 and D2 receptor mechanisms in the abuse-related behavioral effects of cocaine: studies with preferential antagonists in squirrel monkeys. J Pharmacol Exp Ther 334: 556-565.

Achat-Mendes C, Platt DM, Newman AH, Spealman RD (2009). The dopamine D3 receptor partial agonist CJB 090 inhibits the discriminative stimulus but not the reinforcing or priming effects of cocaine in squirrel monkeys. Psychopharmacology (Berl) 206: 73-84. 
Acri JB, Carter SR, Alling K, Geter-Douglass B, Dijkstra D, Wikstrom $\mathrm{H}$ et al (1995). Assessment of cocaine-like discriminative stimulus effects of dopamine D3 receptor ligands. Eur $J$ Pharmacol 281: R7-R9.

Balster RL (1990). Abuse potential of buspirone and related drugs. J Clin Psychopharmacol 10: 31S-37S.

Balster RL, Woolverton WL (1982). Intravenous buspirone selfadministration in rhesus monkeys. J Clin Psychiatry 43: 34-37.

Beardsley PM, Sokoloff P, Balster RL, Schwartz JC (2001). The D3R partial agonist, BP 897, attenuates the discriminative stimulus effects of cocaine and D-amphetamine and is not selfadministered. Behav Pharmacol 12: 1-11.

Bergman J, Roof RA, Furman CA, Conroy JL, Mello NK, Sibley DR et al (2012). Modification of cocaine self-administration by buspirone (Buspar $(\mathrm{B})$ : potential involvement of D3 and D4 dopamine receptors. Int J Neuropsychopharmacol 25: 1-14.

Butelman ER, Harris TJ, Kreek MJ (1999). Effects of E-2078, a stable dynorphin A(1-8) analog, on sedation and serum prolactin levels in rhesus monkeys. Psychopharmacology (Berl) 147: 73-80.

Caine SB, Koob GF (1993). Modulation of cocaine self-administration in the rat through D-3 dopamine receptors. Science 260: 1814-1816

Caine SB, Koob GF (1995). Pretreatment with the dopamine agonist 7-OH-DPAT shifts the cocaine self-administration doseeffect function to the left under different schedules in the rat. Behav Pharmacol 6: 333-347.

Callahan PM, Cunningham KA (1997). Modulation of the discriminative stimulus properties of cocaine: comparison of the effects of fluoxetine with 5-HT1A and 5-HT1B receptor agonists. Neuropharmacology 36: 373-381.

Cinciripini PM, Lapitsky L, Seay S, Wallfisch A, Meyer WJI, Van Vunakis H (1995). A placebo-controlled evaluation of the effects of buspirone on smoking cessation: differences between highand low-anxiety smokers. J Clin Pharmacol 15: 182-191.

Claytor R, Lile JA, Nader MA (2006). The effects of eticlopride and the selective D3-antagonist PNU 99194-A on food- and cocainemaintained responding in rhesus monkeys. Pharmacol Biochem Behav 83: 456-464.

Cole JO (1982). New anxiety agents. Psychopharmacol Bull 18: 45-46.

Di Ciano P (2008). Drug seeking under a second-order schedule of reinforcement depends on dopamine D3 receptors in the baslolateral amygdala. Behav Neurosci 122: 129-139.

Dockens RC, Salazar DE, Fulmore IE, Wehling M, Arnold ME, Croop R (2006). Pharmacokinetics of a newly identified active metabolite of buspirone after administration of buspirone over its therapeutic dose range. J Clin Pharmacol 46: 1308-1312.

Elkashef A, Vocci FJ, Huestis M, Haney M, Budney A, Gruber A et al (2008). Marijuana neurobiology and treatment. Subst Abus 29: 17-29.

Fivel PA (2011). Computer-controlled drug doses for IV drug selfadministration. Exp Clin Psychopharmacol 19: 131-133.

Gal K, Gyertyan I (2003). Targeting the dopamine D3 receptor cannot influence continuous reinforcement cocaine self-administration in rats. Brain Res Bull 61: 595-601.

Gammans RE, Mayol RF, LaBudde JA (1986). Metabolism and disposition of buspirone. Am J Med 80: 41-51.

Gold LH, Balster RL (1992). Effects of buspirone and gepirone on i.v. cocaine self-administration in rhesus monkeys. Psychopharmacology (Berl) 108: 289-294.

Goldberg HL (1984). Buspirone hydrochloride: a unique new anxiolytic agent. Pharmacokinetics, clinical pharmacology, abuse potential and clinical efficacy. Pharmacotherapy 4: 315-324.

Griffith JD, Jasinski DR, Casten GP, McKinney GR (1986). Investigation of the abuse liability of buspirone in alcoholdependent patients. Am J Med 80: 30-35.
Griffiths RR, Lamb RJ, Sannerud CA, Ator NA, Brady JV (1991). Self-injection of barbiturates, benzodiazepines and other sedative-anxiolytics in baboons. Psychopharmacology (Berl) 103: 154-161.

Gyertyan I, Kiss B, Gal K, Laszlovszky I, Horvath A, Gemesi LI et al (2007). Effects of RGH-237 [N-\{4-[4-(3-aminocarbonyl-phenyl)piperazin-1-yl]-butyl\}-4-bromo-benzamide], an orally active, selective dopamine $\mathrm{D}(3)$ receptor partial agonist in animal models of cocaine abuse. J Pharmacol Exp Ther 320: 1268-1278.

Haney M, Spealman R (2008). Controversies in translational research: drug self-administration. Psychopharmacology (Berl) 199: 403-419.

Heidbreder CA, Gardner EL, Xi Z-X, Thanos PK, Mugnaini M, Hagan JJ et al (2005). The role of central dopamine D3 receptors in drug addiciton: a review of pharmacological evidence. Brain Res Rev 49: 77-105.

Heidbreder CA, Newman AH (2010). Current perspectives on selective dopamine $\mathrm{D}_{3}$ receptor antagonists as pharmacotherapeutics for addictions and related disorders. Ann NY Acad Sci 1187: 4-34.

Henningfield JE, Fant RV, Buchhalter AR, Stitzer ML (2005). Pharmacotherapy for nicotine dependence. CA Cancer J Clin 55: 281-299, quiz 322-283, 325.

Herin DV, Rush CR, Grabowski J (2010). Agonist-like pharmacotherapy for stimulant dependence: preclinical, human laboratory, and clinical studies. Ann NY Acad Sci.

Hilleman DE, Mohiuddin SM, Del Core MG, Sketch MH Sr. (1992). Effect of buspirone on withdrawal symptoms associated with smoking cessation. Arch Intern Med 152: 350-352.

Homberg JR, Arends B, Wardeh G, Raaso HS, Schoffelmeer AN, de Vries TJ (2004). Individual differences in the effects of serotonergic anxiolytic drugs on the motivation to self-administer cocaine. Neuroscience 128: 121-130.

ILAR-NRC (1996). Guide for the Care and Use of Laboratory Animals. National Academy Press: Washington, DC, pp 125.

Kleven MS, Barret-Grevoz C, Bruins-Slot L, Newman-Tancredi A (2005). Novel antipsychotic agents with $5-\mathrm{HT}_{1 \mathrm{~A}}$ agonist properties: role of $5-\mathrm{HT}_{1 \mathrm{~A}}$ receptor activation in attenuation of catalepsy induction in rats. Neuropharmacology 49: 135-143.

Koetzner L, Riley AL, Glowa JR (1996). Discriminative stimulus effects of dopaminergic agents in rhesus monkeys. Pharmacol Biochem Behav 54: 517-523.

Kula NS, Baldessarini RJ, Kebabian JW, Neumeyer JL (1994). S$(+)$-aporphines are not selective for human D3 dopamine receptors. Cell Mol Neurobiol 14: 185-191.

Lamas X, Negus SS, Nader MA, Mello NK (1996). Effects of the putative dopamine D3 receptor agonist 7-OH-DPAT in rhesus monkeys trained to discriminate cocaine from saline. Psychopharmacology (Berl) 124: 306-314.

Le Foll B, Goldberg SR, Sokoloff P (2005). D3 receptor and drug dependence: effects on reward or beyond? Neuropharmacology 49: 525-541.

Le Foll B, Schwartz J-C, Sokoloff P (2000). Dopoamine D3 receptor agents as potential new medications for drug addiction. Eur Psychiatry 15: 140-146.

Line SW (1987). Environmental enrichment for laboratory primates. J Am Vet Med Assoc 190: 854-859.

Mahmood I, Sahajwalla C (1999). Clinical Pharmacokinetics and pharmacodynamics of buspirone, an anxiolytic drug. Clin Pharmacokinet 36: 277-287.

Mandrioli R, Mercolini L, Raggi MA (2010). Metabolism of benzodiazepine and non-benzodiazepine anxiolytic-hypnotic drugs: an analytical point of view. Curr Drug Metab 11: 815-829.

Marathe PH, Shen F, Markham P, Greene DS (1999). Pharmacokinetics of buspirone followoing oral administration to rhesus monkeys. J Pharm Pharmacol 51: 601-607.

Martelle JL, Claytor R, Ross JT, Reboussin BA, Newman AH, Nader MA (2007). Effects of two novel D3-selective compounds, NGB 
2904 [N-(4-(4-(2, 3-dichlorophenyl) piperazin-1-yl) butyl)-9Hfluorene-2-carboxamide] and CJB 090 [N-(4-(4-(2, 3-dichlorophenyl) piperazin-1-yl) butyl)-4-(pyridin-2-yl) benzamide], on the reinforcing and discriminative stimulus effects of cocaine in rhesus monkeys. J Pharmacol Exp Ther 321: 573-582.

McRae-Clark AL, Carter RE, Killeen TK, Carpenter MJ, Wahlquist AE, Simpson SA et al (2009). A placebo-controlled trial of buspirone for the treatment of marijuana dependence. Drug Alc Depend 105: 132-138.

Mello NK (2005). Marian W Fischman memorial lecture (2004). Evaluation of drug abuse treatment medications: concordance between clinical and preclinical studies. In: Dewey WL (ed). Problems of Drug Dependence 2004: Proceedings of the 66th Annual Scientific Meeting, The College on Problems of Drug Dependence, Inc. US Department of Health and Human Services, National Institutes of Health: Bethesda, MD, pp 82-104.

Mello NK, Negus SS (1996). Preclinical evaluation of pharmacotherapies for treatment of cocaine and opiate abuse using drug self-administration procedures. Neuropsychopharmacology 14: 375-424.

Mello NK, Negus SS (2007). Effects of d-amphetamine and buprenorphine combinations on speedball (cocaine + heroin) self-administration by rhesus monkeys. Neuropsychopharmacology 32: 1985-1994.

Mello NK, Negus SS, Lukas SE, Mendelson JH, Sholar JW, Drieze JM (1995). A primate model of polydrug abuse: cocaine and heron combinations. J Pharmacol Exp Ther 274: 1325-1337.

Muller CP, Carey RJ, Huston JP, De Souza Silva MA (2007). Serotonin and psychostimulant addiction: focus on $5-\mathrm{HT}_{1 \mathrm{~A}^{-}}$ receptors. Prog Neurobiol 81: 133-178.

Nader MA, Barrett JE (1990). Effects of chlordiazepoxide, buspirone, and serotonin receptor agonists and antagonists on responses of squirrel monkeys maintained under second-order schedules of intramuscular cocaine injection or food presentation. Drug Dev Res 20: 5-17.

Nader MA, Green KL, Luedtke RR, Mach RH (1999). The effects of benzamide analogues on cocaine self-administration in rhesus monkeys. Psychopharmacology (Berl) 147: 143-152.

Nader MA, Mach RH (1996). Self-administration of the dopamine D3 agonist 7-OH-DPAT in rhesus monkeys is modified by previous cocaine exposure. Psychopharmacology (Berl) 125: $13-22$.

Negus SS, Mello NK (2003). Effects of chronic $d$-amphetamine treatment on cocaine- and food-maintained responding under a second-order schedule in rhesus monkeys. Drug Alc Depend 70: 39-52.

Newman AH, Blaylock BL, Nader MA, Bergman J, Sibley DR, Skolnick P (2012). Medication discovery for addiction: translating the dopamine D3 receptor hypothesis. Biochem Pharmacol 84: 882-890.

Newman AH, Grundt P, Nader MA (2005). Dopamine D3 receptor partial agonists and antagonists as potential drug abuse therapeutic agents. J Med Chem 48: 3663-3679.

Newman-Tancredi A, Gavaudan S, Conte C, Chaput C, Touzard M, Verriele L et al (1998). Agonist and antagonist actions of antipsychotic agents at 5-HT1A receptors: a [35S]GTPgammaS binding study. Eur J Pharmacol 355: 245-256.

Peng X-Q, Ashby CR, Spiller K, Li X, Li J, Thomasson N et al (2009). The preferential dopamine D3 receptor antagonist S33138 inhibits cocaine reward and cocaine-triggered relapse to drug-seeking behavior in rats. Neuropharmacology 56: $752-760$.
Pilla M, Perachon S, Sautel F, Garrido F, Mann A, Wermuth CG et al (1999). Selective inhibition of cocaine-seeking behaviour by a partial dopamine D3 receptor agonist. Nature 400: 371-375.

Prinssen EPM, Colpaert FC, Koek W (2002). 5- $\mathrm{HT}_{1 \mathrm{~A}}$ receptor activation and anti-cataleptic effects: high-efficacy agonists maximally inhibit haloperidol-induced catalepsy. Eur J Pharmacol 453: 217-221.

Prinssen EPM, Koek W, Colpaert FC, Kleven MS (2000). Repeated treatment with 8-OH-DPAT induces tolerance to its ability to produce the $5-\mathrm{HT}_{1 \mathrm{~A}}$ behavioural syndrome, but not to its ability to attenuate haloperidol-induced catalepsy. Behav Pharmacol 11: 299-305.

Rapoza D (1993). Buspirone fails to affect the discriminative stimulus effects of cocaine. Pharmacol Biochem Behav 45: 179-183.

Rijnders HJ, Slangen JL (1993). The discriminative stimulus properties of buspirone involve dopamine-2 receptor antagonist activity. Psychopharmacology (Berl) 111: 55-61.

Rush CR, Critchfield TS, Troisi JR, Griffiths RR (1995). Discriminative stimulus effects of diazepam and buspirone in normal volunteers. J Exp Anal Behav 63: 277.

Sheskin DJ (2000). Handbook of Parametric and Nonparametric Statistical Procedures. 2nd edn. Chapman and Hall: Boca Raton, FL.

Song R, Yang R-F, Wu N, Su R-B, Li J, Peng X-Q et al (2012). YQ14: a novel dopamine $\mathrm{D} 3$ receptor antagonist that inhibits cocaine self-administration in rats and mice, but not in D3 receptorknockout mice. Addict Biol 17: 259-273.

Spealman RD (1996). Dopamine D3 receptor agonists partially reproduce the discriminative stimulus effects of cocaine in squirrel monkeys. J Pharmacol Exp Ther 278: 1128-1137.

Tallman F, Primus RJ, Brodbeck R, Cornfield L, Meade R, Woodruff K et al (1997). I. NGD 94-1: identification of a novel, high-affinity antagonist at the human dopamine D4 receptor. J Pharmacol Exp Ther 282: 1011-1019.

Weinstein AM, Gorelick DA (2011). Pharmacological treatment of cannabis dependence. Curr Pharm Des 17: 1351-1358.

West R, Hajek P, McNeil A (1991). Effect of buspirone on cigarette withdrawal symptoms and short-term abstinence rates in a smokers clinic. Psychopharmacology (Berl) 104: 91-96.

Winhusen T, Brady KT, Stitzer M, Woody G, Lindblad R, Kropp F et al (2012). Evaluation of buspirone for relapse-prevention in adults with cocaine dependence: an efficacy trial conducted in the real world. Contemp Clin Trials.

Wong H, Dockens RC, Pajor L, Yeola S, Grace JEJ, Stark AD et al (2007). 6-Hydroxybuspirone is a major active metabolite of buspirone: assessment of pharmacokinetics and 5-hydroxytryptamine $_{1 \mathrm{~A}}$ receptor occupancy in rats. Drug Metab Dispos 35: $1387-1392$

Xi Z-X, Gardner EL (2007). Pharmacological actions of NGB 2904, a selective dopamine D3 receptor antagonist, in animal models of drug addiction. CNS Drug Rev 13: 240-259.

Xi Z-X, Gilbert JG, Pak AC, Ashby CR Jr, Heidbreder CA, Gardner EL (2005). Selective dopamine D3 receptor antagonism by SB$277011 \mathrm{~A}$ attenuates cocaine reinforcement as assessed by progressive-ratio and variable-cost-vriable-payoff fixed-ratio cocaine self-adminlstration in rats. Eur J Neurosci 21: 3427-3438.

Xi Z-X, Newman AH, Gilbert JG, Pak AC, Peng X-Q, Ashby CR Jr et al (2006). The novel dopamine D3 receptor antagonist NGB 2904 inhibits coaine's rewarding effects and cocaine-induced reinstatement of drug-seeking behaivor in rats. Neuropsychopharmacology 31: 1393-1405. 